\title{
Leaflet Boron Concentration Reduced with Hybrid Pistacia vera Rootstocks
}

\author{
Craig E. Kallsen \\ University of California Cooperative Extension, 1031 S. Mt. Vernon \\ Avenue, Bakersfield, CA 93307
}

\author{
Dan E. Parfitt \\ Department of Plant Science, University of California, One Shields \\ Avenue, Davis, CA 95616
}

Additional index words. chloride, Pistacia integerrima, 'Platinum', rootstock breeding, salt tolerance, sodium, UCB-1

\begin{abstract}
Excessive boron (B) in soil and water is a problem for pistachio (Pistacia vera L.) production in the San Joaquin Valley (SJV) of California. Although amenable, leaching of $B$ requires more water than chlorine $(\mathrm{Cl})$ or sodium $(\mathrm{Na})$ and is increasingly difficult as $B$ in irrigation water increases. The lack of subsurface drainage to the ocean increases soil salinity in many growing areas, especially on the west side of the SJV where $B$ is often excessive natively in the soil and water. Pistachio rootstocks that can tolerate or exclude B may be a partial solution. For the past decade in California, the dominant rootstock has been seedlings and clonal selections of University of California Berkeley 1 (UCB-1), which is a hybrid of $P$. atlantica $\times P$. integerrima. This reliance on a genetically similar pool of rootstocks has constrained Pistacia's genetic potential for adapting to high-salt environments. This study compared scion and rootstock leaflet $B$ concentration of novel hybrid experimental rootstocks with variable percentages of $P$. vera and $P$. integerrima heritage with UCB-1. Rootstocks with $P$. vera heritage limited B in both rootstock and scion leaflets compared with UCB-1. In six trials conducted over several years, leaflet $B$ in ungrafted hybrid rootstocks having $62.5 \%$ to $75 \%$ P. vera and $25 \%$ to $37.5 \% P$. integerrima heritage had $27.6 \%$ to $43.1 \%$ lower B leaflet concentration than did UCB-1. Depending on the experiment and year, grafted rootstocks having $37.5 \% P$. vera and $62.5 \% P$. integerrima heritage had $46.8 \%$ to $70.8 \%$ lower $B$ scion leaflet concentration than did UCB-1. Genetic variation in B uptake in Pistacia species and interspecific hybrids, and among individual seedlings within populations, allows the breeding of pistachio rootstocks more tolerant of excess $B$.
\end{abstract}

California's best producing pistachio orchards are often grown in alkaline, calcareous, and boric soils of the southwestern San Joaquin Valley (SJV). Pistachio, unlike most perennial fruit and nut crops, is moderately $\mathrm{B}, \mathrm{Na}$, and $\mathrm{Cl}$ tolerant (Sanden et al., 2016). However, in lower-elevation western SJV, soil and groundwater B and other salt levels are often excessive, even for pistachio (Ashworth et al., 1985; Banuelos, 2014; Bingham et al., 1970; Burton et al., 2012; Christensen et al., 1974). For pistachio production in California using UCB-1 rootstocks

Received for publication 9 Aug. 2021. Accepted for publication 5 Oct. 2021.

Published online 14 December 2021

We thank Sierra Gold Nurseries for the donation of the commercial rootstocks; the cooperating growers including Barton Heuler and Alan Scroggs of MidValley Ranch; the Starrh family of Starrh and Starrh Growers; Wonderful Orchards for providing land, materials and labor for the field trials and the California Pistachio Research Board for financial assistance; and Louise Ferguson, Bruce Lampinen and the anonymous reviewers for their comments and suggestions.

C.E.K. is the corresponding author. E-mail: cekallsen@ucdavis.edu.

This is an open access article distributed under the CC BY-NC-ND license (https://creativecommons. org/licenses/by-nc-nd/4.0/). and existing scion cultivars, soil B is excessive if leaflet concentrations exceed $800 \mathrm{ppm}$ (Sanden et al., 2016). Generally, irrigation water in excess of 3 ppm B restricts it use in irrigated agriculture (Ayers and Westcot, 1985). Boron toxicity is more prevalent where high-pH clay soils predominant, water quantity and quality are limited, and B is natively high in the soil (Banuelos, 2014; Communar and Keren, 2006; Goldberg and Glaubig, 1986; Su and Suarez, 2004). Boron may require twice as much water to leach from alkaline soils than $\mathrm{Na}$ or $\mathrm{Cl}$ (Hanson et al., 2006) and tends to accumulate in the soil profile. The SJV is an irrigated basin with no subsurface drainage to the ocean. Irrigated agriculture, especially at the lower elevations, is increasing the salt load in this basin to ultimately unsustainable levels (Banuelos, 2014; Quinn, 2014; Oster and Wichelns, 2014).

Boron is essential in pistachio nutrition and appears to be important in flowering, pollen viability, and nut set (Brown, 1995). August leaflet concentrations of 150 to 250 ppm B on a dry weight (DW) basis are considered adequate for pistachio production (Beede et al., 2016; Brown et al., 1993). Within a crop species, the boundary between B deficiency and toxicity can be small
(Brdar-Jokanović, 2020). For pistachio, high soil and water B levels will produce increasingly higher scion leaflet $\mathrm{B}$ with initial leaf symptoms ranging from only marginal necrosis in some leaves to complete necrosis and canopy defoliation by midsummer at high concentrations (Beede et al., 2016). Boron in the necrotic portion of affected leaves was in excess of $3000 \mathrm{ppm}$ in 'Kerman' grafted to $P$. integerrima rootstock in an orchard on the west side of the SJV (L. Ferguson, personal communication).

The ability of a rootstock to exclude or otherwise tolerate excessive B would be useful for growing pistachio in high-B soils. While $\mathrm{Na}$ and $\mathrm{Cl}$ typically receive the greatest attention in addressing soil and water salinity, B can be a critical parameter. The growth of young 'Kerman' trees, growing in sand culture high in $\mathrm{Na}, \mathrm{Cl}$, and $\mathrm{B}$, and grafted to three different rootstocks, was more negatively associated with the $\mathrm{B}$ concentration in the water than the $\mathrm{Na}$ or $\mathrm{Cl}$ (Ferguson et al., 2002). Furthermore, this same study showed that leaf B concentrations in 'Kerman' scions were 1500 to $2500 \mathrm{mg} \cdot \mathrm{kg}^{-1} \mathrm{DW}$ on $P$. integerrima and UCB-1, but 1000 to $1500 \mathrm{mg} \cdot \mathrm{kg}^{-1} \mathrm{DW}$ when grafted to $P$. atlantica. These differences among pistachio species in tolerance or exclusion of B suggest that plant breeding may be applicable for developing novel rootstocks (Brdar-Jokanovic, 2020).

A successful rootstock must tolerate or have resistance to prevalent soil diseases. Pistacia atlantica, as a rootstock, is highly susceptible to Verticillium Wilt disease caused by Verticillium dahliae (Ashworth et al., 1985; Holtz and Teviotdale, 2016). Hokmabadi et al. (2006) in a greenhouse study, reported 1-yearold seedling $P$. vera rootstocks had a high-B tolerance in trials using irrigation water with $40 \mathrm{mg} \cdot \mathrm{L}^{-1}$. At the end of $60 \mathrm{~d}$, leaf B had plateaued at only about $300 \mathrm{ppm}$. However, $P$. vera, as a rootstock or growing on its own roots, is susceptible to Phytophthora species under fully irrigated conditions (Banihashemi, 1995; Fichtner et al., 2017; Kallsen and Parfitt, unpublished data), which makes them unsuitable as rootstocks under California conditions. The apparent B tolerance of $P$. vera suggests its use as a parent in crosses with more vigorous and disease-resistance species to generate rootstocks for high-B soils.

The objective of our study was to compare B concentrations of novel $P$. integerrima $\times P$. vera hybrid rootstocks from the University of California breeding program with the current industry standard UCB-1 with a goal of identifying rootstocks adapted to high-B soils. Leaflet B was chosen as a basis of comparison, in both potted rootstock plants and scions grafted to rootstock in commercial orchards, because higher leaflet B has been associated with increased leaf necrosis (Ashworth et al., 1985; Beede et al., 2016; Ferguson et al., 2002; Picchioni et al., 1991).

\section{Materials and Methods}

Plant rootstock materials

$U C B-1$ seedling rootstock. UCB-1, the most commonly planted in California over 
the past decade, is from a cross of a single female $P$. atlantica tree with a single $P$. integerrima tree. The female tree was designated as LAS_At_FNE_R1_T1 and the male as LAS_Int_FNE_R3_T1 (L. Ferguson, personal communication).

'Platinum' rootstock. Platinum' is a clonal rootstock propagated by tissue culture and was invented by a commercial nursery (Anderson and Puryear, 2002). The original seedling was selected from among the offspring of a $P$. integerrima female and a $P$. atlantica male, the reciprocal of the cross that gave UCB-1.

PVI2 and PVI3 seedling rootstocks. The rootstocks PVI2 and PVI3 are two separate interspecific hybrid female lineages each resulting from open pollinated crosses of single interspecific hybrid females $[P$. vera $\times(P$. vera $\times P$. integerrima $)$ ] with three $P$. integerrima males. The hybrid female parents were designated as BakO-SRT1 and LC-R1T58, for the PVI2 and PVI3 rootstock lineages, respectively. The authors made the crosses in 2009 and 2016. Based on their parentage, these seedling rootstocks are $62.5 \% P$. integerrima and $37.5 \%$ P. vera.

End-2 rootstocks or seedling trees. End-2 seedlings were produced within the UC breeding program in 2010 and 2011 using diverse pairwise crosses of $P$. vera $\times P$. integerrima hybrid parents. They are $62.5 \%$ to $75 \% P$. vera and $25 \%$ to $37.5 \% P$. integerrima. These seedlings were evaluated as grafted trees or as ungrafted seedlings.

$P$. vera seedling trees. Ungrafted $P$. vera seedling trees were from pairwise crosses of $P$. vera parents in the UC breeding program.

\section{Plant and soil analysis}

Leaflets were the predominant plant tissue sampled. Trees sampled were not treated with foliar nutrient sprays containing $\mathrm{B}$ or $\mathrm{Cl}$, so plant nutrient concentrations of these two elements in tissue samples were the result of soil uptake and translocation. Leaflet, shoot, trunk, and nut samples collected in orchards were collected in paper bags in the field and transported in a cooler ca. $4.5^{\circ} \mathrm{C}$. Leaflets and shoots were washed with vigorous agitation under distilled water. Leaflet samples were oven dried for three or four days at $60^{\circ} \mathrm{C}$ before grinding and analysis. Plant shoots and nuts were dried for $10 \mathrm{~d}$ before laboratory analysis.

Plant and soil analyses were conducted at the University of California Agriculture and Natural Resources (UC ANR) Laboratory located on the university campus in Davis, CA. Unless otherwise noted, plant tissues were analyzed for total N, P, K, S, Ca, Mg, Na, B, Cl, $\mathrm{Fe}, \mathrm{Zn}, \mathrm{Cu}$, and $\mathrm{Mn}$ as described by the UC ANR Laboratory (2021). Thermal conductivity/ IR detection was used for N (AOAC, 2016), a water extraction and analysis by ion chromatography with conductivity detection for $\mathrm{Cl}$ (Jones, 2001) and nitric acid/hydrogen peroxide microwave digestion and determination by inductively coupled plasma atomic emission spectrometry for the remainder (Meyer and Keliher, 1992; Sah and Miller, 1992). Values were expressed on a DW basis $(\mathrm{w} / \mathrm{w})$. Unless otherwise noted, soil elements were determined as follows: $\mathrm{Ca}, \mathrm{Mg}, \mathrm{Na}, \mathrm{Cl}, \mathrm{B}$, and $\mathrm{HCO}_{3}$, as saturated paste extracts; $\mathrm{Zn}, \mathrm{Mn}, \mathrm{Cu}$, and $\mathrm{Fe}$ as diethylenetriaminepentaacetic acid extraction; and NO3-N, Olsen-P, and available K using various extraction methods described by Thomas (1982) and UC ANR Laboratory (2021).

\section{Irrigation and fertilization}

Irrigation and fertilization of the trials located within commercial orchards were under the control of the cooperating growers, whose objective was to maximize nut yields by meeting the full ET and nutrient requirements of the trees in the orchard. The experimental orchards were irrigated with efficient, low-volume drip systems and major nutrients applied through the irrigation systems.

\section{Statistical analyses}

Data were analyzed using ANOVA (StatSoft, Inc, Tulsa, OK). The experimental designs (either randomized complete block or completely randomized) are described within the individual experiment descriptions.

\section{Experiment descriptions}

Experimental designs. Other than in Expt. 1 , the objectives of these diverse experiments were to compare horticultural characteristics, such as yield and nut quality, of a number of commercial cultivars grafted to experimental rootstocks under differing commercial conditions. Although the experiments were not specifically designed to quantify difference in $B$ leaflet concentration among rootstocks of varying $P$. vera heritage, the plant materials and the randomized and replicated scientific designs of these experiments made them amenable to making these comparisons under a variety of commercial scions and field conditions over years.

Expt. 1. Boron in leaves and wood of potted trees of ungrafted PV12 seedlings were compared with UCB-1 seedlings grown at the UC Cooperative Extension office in Bakersfield, CA. This experiment was designed to demonstrate plant tissue uptake under a condition of low and high B availability, but not to quantify the relationship between applied B on rootstock growth or tissue $\mathrm{B}$ concentrations. PV12 seedlings were produced from a single female $P$. integerrima $\times P$. vera tree crossed with a mixture of pollen from three different $P$. integerrima males. Bagged flowers on the mother tree were pollinated and rebagged on 18 Mar. 2016. Resulting seeds were harvested in Fall 2016. The seeds with split shells were sun dried for five days and stored in a cold room at $3.0^{\circ} \mathrm{C}$. On 20 Mar. 2017 , the seeds were planted in conical plastic pots $(64 \mathrm{~mm}$ diameter at the top and $254 \mathrm{~mm}$ deep) in a mix of $50 \%$ potting soil consisting of wood products, perlite, sphagnum, and peatmoss (Moisture control potting mix, Miracle-Gro Lawn Products, Inc., Marysville, OH), 25\% perlite and $25 \%$ sand $\mathrm{v} / \mathrm{v}$. After planting, the pots were placed outside under an automated irrigation system. The potted trees in this experiment grew under hot, dry ambient weather conditions in Bakersfield through the summer and allowed to go dormant naturally in the fall and winter. On 21 Mar. 2018, UCB-1 seedling rootstocks, $\approx 100 \mathrm{~mm}$ in height and growing in peat pellets, were purchased from a commercial nursery (Wonderful Nurseries, Madera, CA) and potted as described for the 'PV12' seedlings and placed with them in the nursery.

Both rootstocks were replanted on 19 Apr. 2018 into $6.2 \mathrm{~L}$ pots $(152 \mathrm{~mm}$ diameter and $406 \mathrm{~mm}$ deep). The pots were painted white to reduce heat absorption. The potting soil was a mix of $15 \%$ by volume of sand and $85 \%$ a commercial potting mix (Moisture control potting mix, Miracle-Gro Lawn Products, Inc., Marysville, OH). Each pot was irrigated by a $4 \mathrm{~L} \cdot \mathrm{h}^{-1}$ drip emitter attached to an automated irrigation system. As the trees grew, they were topped at a height of $\approx 700 \mathrm{~mm}$. During the summer, it was necessary to irrigate twice a day to maintain tree leaf turgor. Irrigation volume was adjusted throughout the growing season to minimize but not obviate drainage from the pots. Applied water or drainage were not measured.

There were four treatments. The two rootstock cultivars either were grown with added B (referred to as " $+\mathrm{B}$ ") or without added B ("control"). The pots were placed in a randomized complete block design with four blocks. Within each block, there were eight trees, two for each of the four treatments. When sampled, the two trees of each treatment were sampled together and results are for the average of the pair.

The potting medium contained about 0.15 ppm of B at planting. Boron was supplied at intervals to the $+\mathrm{B}$ treatments as disodium octaborate tetrahydrate $\left[\left(\mathrm{Na}_{2} \mathrm{~B}_{8} \mathrm{O}_{13} \bullet 4_{2} \mathrm{O}\right)\right.$ (Solubor, 20 Mule Team Borax, Boron, CA)]. The applied product was $20.5 \% \mathrm{~B}$ w/w. From planting in Apr. 2018 to the first tissue sampling in June 2019, a total of $10.6 \mathrm{~g}$ of this chemical was applied to the $+\mathrm{B}$ treatments and $3 \mathrm{~g}$ were added from the first sampling period to the final sampling period in Aug. 2020. The initial $6.6 \mathrm{~g}$ of $\mathrm{B}$ was applied to the $+\mathrm{B}$ treatments as a $10 \mathrm{mg} \cdot \mathrm{L}^{-1}$ solution but this procedure was changed in July 2018 to placing the dry powder on the potting mix surface below the emitter. This latter procedure reduced the amount of pot drainage and application time. The relatively small amount of $\mathrm{B}$ in the additional general fertilizer treatments, applied to both the $+\mathrm{B}$ and control treatments, and what may have been in the irrigation water were not considered.

Fully expanded leaflets were sampled 19 June 2019 and 4 Aug. 2020 for analysis of N, $\mathrm{P}, \mathrm{K}, \mathrm{S}, \mathrm{B}, \mathrm{Ca}, \mathrm{Mg}, \mathrm{Zn}, \mathrm{Mn}, \mathrm{Fe}, \mathrm{Cu}, \mathrm{Cl}$, and $\mathrm{Na}$. In addition, on 4 Aug. 2020, the potting mix and the lower-trunk tissue (from $10 \mathrm{~mm}$ to $50 \mathrm{~mm}$ above soil level) were sampled for B. These lower trunks were about $16 \mathrm{~mm}$ in diameter. Boron in the potting mix was determined by a total nitric acid digestion procedure (UC ANR Laboratory, 2021).

Expt. 2. UCB-1, PVI2, and PVI3 seedling rootstocks were planted in a single row and grafted to 'Golden Hills' within a commercial 
orchard $16 \mathrm{~km}$ west of Buttonwillow, CA. Two trees of each rootstock were planted randomly in each of three blocks (six trees of each rootstock in total) in Oct. 2011 and grafted in July 2012. Tree spacing was $5.2 \mathrm{~m}$ between trees within a row and $6.1 \mathrm{~m}$ between rows.

The PVI2 and PVI3 rootstocks were produced by crosses made in 2009 in the UC breeding program and the resulting rootstock seed propagated as described in Expt. 1. The UCB-1 rootstocks were obtained from a commercial nursery (Sierra Gold Nurseries, Yuba City, CA). Soil in this block was a Panoche clay loam (USDA, 2021). Based on testing in 2020, this soil had an estimated cation exchange capacity (CEC) of $33.7 \mathrm{meq} \cdot 100 \mathrm{~g}^{-1}$ of soil, a $\mathrm{pH}$ of 7.8, an electrical conductivity (EC) of 3.0 $\mathrm{dS} \cdot \mathrm{m}^{-1}$, and a saturation percentage (SP) of $46.3 \%$ in the top $0.9 \mathrm{~m}$ of soil profile (UC ANR Laboratory, 2021). Boron in saturation paste extracts was $5.9,3.4$, and $2.6 \mathrm{mg} \cdot \mathrm{L}^{-1}$ in 2018 , 2019 , and 2020, respectively, while $\mathrm{Cl}$ was $35.9,9.8$, and $13.8 \mathrm{meq} \cdot \mathrm{L}^{-1}$ in these years.

Soil was sampled once each year on 23 July 2018, 27 Aug. 2019, and 12 Aug. 2020. A $76 \mathrm{~mm}$-diameter auger was used to drill a single $0.9 \mathrm{~mm}$ deep hole per block. The holes were located $300 \mathrm{~mm}$ away from each drip emitter (parallel to the irrigation hose) and then $300 \mathrm{~mm}$ perpendicular from that point. Soil was removed from the hole in three $300 \mathrm{~mm}$ increments. Equal quantities of soil were removed from each increment and then pooled into a single sample that was sent to the laboratory.

Leaflet samples were taken each year from fully expanded, non-terminal leaflets on nonfruiting branches $1.5 \mathrm{~m}-2 \mathrm{~m}$ aboveground level in all quadrants of the tree canopy. Sixty leaflets per rootstock were collected for each of the three blocks for a total of nine samples for the trial. Leaflet samples were taken 22 Aug. 2017, 23 July 2018, 27 Aug. 2019, and 12 Aug. 2020.

From each tree in the experiment, a stem sample, about $10 \mathrm{~mm}$ in diameter and $75 \mathrm{~mm}$ long, was taken on 8 Aug. 2018 from the distal ends of vegetative shoots produced in late spring and growing from non-bearing branches. Leaves were removed from the stems. Eight entire nuts per tree, including the hull, but not any peduncle material, were collected, and washed as described for the leaflet and shoot material. A sample of bark, cambium, and underlying wood $25 \mathrm{~mm} \times 25 \mathrm{~mm}$ was removed from the west and east sides of the rootstock portion of the trunk about $150 \mathrm{~mm}$ aboveground level on 9 Sept. 2018. Before this sample was removed, the outer bark was scrubbed vigorously with a stiff brush while forcefully sprayed with distilled water. The sample consisted of the bark, and the underlying wood to a depth of $3 \mathrm{~mm}$ below the cambium layer. Two samples were taken from each tree in each block. The individual PVI2 and PVI3 samples were pooled into a single sample for each block. The samples were analyzed for $\mathrm{B}$ and $\mathrm{Na}$.

Both the rootstock and scion bark and underlying wood were sampled on 12 Aug.
2020. Individual samples were taken from the trunks as done in 2018, except the location of sample removal was $200 \mathrm{~mm}$ above the highest point of the graft union on the 'Golden Hills' scion trunk, and $200 \mathrm{~mm}$ below the lowest point of the graft union on the rootstock. UCB-1, PVI2, and PVI3 samples were analyzed for $\mathrm{B}, \mathrm{Na}$, and $\mathrm{Cl}$.

For yield determination, nuts were harvested during the first week in September for 4 years (2017-20). At the trial sites, harvest readiness was determined in consultation with cooperating growers (based on split nut percentage and hull loosening from the shell). Nuts from the two trees on the same rootstock within a block were pooled, weighed and a $9.1 \mathrm{~kg}$ green-weight sample collected. These samples were transported to a pistachio processor on the day of harvest for nut quality evaluation. At the processing plant, each sample was weighed fresh, hulled, dried, and evaluated by inspectors trained by the U.S. Department of Agriculture (California Pistachio Commission, 1990). The percentage of edible, split inshell nuts, shelling stock (split nuts with a damaged shell that must be removed), closed-shell nuts (nuts with an edible kernel but are not split), were scored as were nuts with insect damage, dark stains, adhering hulls and other rejects. Sample results were used to calculate the percentage by weight, adjusted to $5 \%$ moisture, of the marketable yield (total weight of edible split inshell nuts plus the weight of kernels from shelling stock and closed-shell nuts).

Expt. 3. The rootstocks and the design of Expt. 3 were similar to Expt. 2, however, with a different cooperating grower, scion, planting date, and soil type. Scions of 'Gumdrop' were grafted to UCB-1, PV-I2, and PVI3 seedling rootstocks planted in a single row within a larger commercial orchard $32 \mathrm{~km}$ west of Delano, CA. Two to four trees of each rootstock were planted randomly in each of the three blocks in Mar. 2015 and grafted in July 2015. A commercial nursery provided the UCB-1 rootstocks. Tree spacing was $5.2 \mathrm{~m}$ between trees within a row and $5.8 \mathrm{~m}$ between rows. Soil in this block was a poorly drained Nahrub clay (USDA, 2021) and based on testing in 2020, had an estimated CEC of $39.4 \mathrm{meq} \cdot 100 \mathrm{~g}^{-1}$ of soil, a $\mathrm{pH}$ of 8.2 , an EC of $3.6 \mathrm{dS} \cdot \mathrm{m}^{-1}$, and an SP of $85 \%$ in the top $0.9 \mathrm{~m}$ of soil profile (UC ANR Laboratory, 2021). Boron and $\mathrm{Cl}$ in saturation paste extracts were $2.2 \mathrm{mg} \cdot \mathrm{L}^{-1}$ and $23.1 \mathrm{meq} \cdot \mathrm{L}^{-1}$, respectively, in 2020 . Three soil samples were taken, one from each block, on 24 July 2020 in the same manner as in Expt. 2. On the same date, leaflets were collected from two to four trees from the three rootstock cultivars and pooled by cultivar in each block. Leaflet samples were collected and processed as in Expt. 2.

Expt. 4. Scions of 'Lost Hills' were grafted to End-2, UCB-1, and 'Platinum' rootstocks planted in a commercial orchard $16 \mathrm{~km}$ west of Wasco, CA. Rootstocks were planted on 22 Feb. 2013 and grafted in July and August of the same year. Two hundred sixty End-2, ten UCB-1, and ten 'Platinum' rootstocks were planted at a commercial tree spacing of $5.8 \mathrm{~m}$ between rows and $5.2 \mathrm{~m}$ between trees. Soil in this block was a Garces silt loam (USDA, 2021) with an estimated CEC of $30.8 \mathrm{meq} \cdot 100 \mathrm{~g}^{-1}$, a $\mathrm{pH}$ of 7.9 , an EC of $3.2 \mathrm{dS} \cdot \mathrm{m}^{-1}$, and a SP of $31.0 \%$ in the top $0.9 \mathrm{~m}$ of soil profile as determined in 2020 (UC ANR Laboratory, 2021). Boron and $\mathrm{Cl}$ in saturation paste extracts were $0.69 \mathrm{mg} \cdot \mathrm{L}^{-1}$ and $6.5 \mathrm{meq} \cdot \mathrm{L}^{-1}$, respectively, in 2020.

The study evaluated rootstock progeny derived from 21 different parental closed crosses of intergeneric Pistacia hybrids and as a class identified at End-2 rootstocks. Parent materials of these progeny were trees in existing collections and/or progeny from earlier crosses. Mature nuts from these crosses were harvested in the fall, stored during the winter at a temperature of $1.1^{\circ} \mathrm{C}$ and then germinated in late winter or early spring in pots. About 260 of these seedling rootstocks were selected, based on their initial vigor, and planted randomly in the trial area with 10 UCB-1 and 10 'Platinum' rootstock controls obtained from commercial nurseries.

Five soil samples were taken across the trial area on 9 July 2020 in five discreet locations (NW, NE, Central, SW, and SE quadrants) as in Expt. 2. On the same date, leaflets were collected, and pooled, from two to five trees from End-2, UCB-1 and 'Platinum' rootstocks in each of these discreet locations and processed as in Expt. 2. Data from this experiment were analyzed in a randomized, complete block design with five blocks with a single replication per block.

Expt. 5. A seedling selection trial was planted $16 \mathrm{~km}$ west of Wasco, CA in Spring 2012. The seedling trees were bred from 53 different crosses in 2010 and 2011 and propagated as described in Expt. 1. Most were $100 \%$ P. vera but some were hybrids $(75 \% P$. vera, $25 \%$ P. integerrima). Trees were planted randomly in two rows, $5.8 \mathrm{~m}$ apart, with trees planted $1.2 \mathrm{~m}$ apart within the row. Soil in this block was a Garces silt loam (USDA, 2021) with an estimated CEC of 24.4, an EC of 0.8 $\mathrm{dS} \cdot \mathrm{m}^{-1}$, a $\mathrm{pH}$ of 7.9 , and an SP of 30.2 in the top $0.9 \mathrm{~m}$ of soil profile determined by testing in 2020 (UC ANR Laboratory, 2021). Boron, $\mathrm{Cl}$, and $\mathrm{Na}$ in saturation paste extracts were $0.31 \mathrm{mg} \cdot \mathrm{L}^{-1}, \quad 2.66 \mathrm{meq} \cdot \mathrm{L}^{-1}$, and 5.72 meq $\cdot \mathrm{L}^{-1}$, respectively, in 2020 .

On 14 July 2020, leaflet tissue and soil samples were collected in areas of the trial where seedling trees with $100 \%$ P. vera were growing adjacent to hybrid trees. Separate leaflet samples (method described for Expt. 2 ) were collected from five or six individuals and pooled by type ( $P$. vera or hybrid). The soil was sampled in five locations, adjacent to trees where leaflets were sampled. Data were analyzed as a completely randomized experimental design.

\section{Results}

Of all the elements tested, only $\mathrm{B}$ and $\mathrm{Cl}$ consistently and $\mathrm{Na}$ and $\mathrm{K}$ occasionally, showed differences in element concentration 
Table 1. Boron (B) and chloride $(\mathrm{Cl})$ concentration in leaflet and trunk tissue of ungrafted UCB-1 and PVI2 rootstocks in the Expt. 1 pots, 2019-20.

\begin{tabular}{|c|c|c|c|c|c|}
\hline $\mathrm{Yr}^{\mathrm{Z}}$ & Rootstock & Treatment $^{z}$ & Tissue type or potting medium & $\mathrm{B}\left(\mathrm{mg} \cdot \mathrm{kg}^{-1}\right)$ & $\mathrm{Cl}(\%)$ \\
\hline \multirow[t]{4}{*}{$\overline{2019}$} & UCB-1 & $+\mathrm{B}$ & Leaflet & $1152 \mathrm{a}^{\mathrm{y}}$ & $0.16 \mathrm{a}$ \\
\hline & UCB-1 & Control & Leaflet & $94 \mathrm{c}$ & $0.17 \mathrm{a}$ \\
\hline & PVI2 & $+\mathrm{B}$ & Leaflet & $656 \mathrm{~b}$ & $0.29 \mathrm{~b}$ \\
\hline & PVI2 & control & Leaflet & $61 \mathrm{c}$ & $0.30 \mathrm{~b}$ \\
\hline \multirow[t]{12}{*}{2020} & UCB-1 & $+\mathrm{B}$ & Leaflet & $831 \mathrm{a}$ & $0.23 \mathrm{a}$ \\
\hline & UCB-1 & control & Leaflet & $196 \mathrm{c}$ & $0.25 \mathrm{a}$ \\
\hline & PVI2 & $+\mathrm{B}$ & Leaflet & $602 \mathrm{~b}$ & $0.72 \mathrm{~b}$ \\
\hline & PVI2 & control & Leaflet & $184 \mathrm{c}$ & $0.78 \mathrm{~b}$ \\
\hline & UCB-1 & $+\mathrm{B}$ & Rootstock trunk & $21 \mathrm{a}$ & $n a^{x}$ \\
\hline & UCB-1 & control & Rootstock trunk & $10 \mathrm{~b}$ & na \\
\hline & PVI2 & $+\mathrm{B}$ & Rootstock trunk & $20 \mathrm{a}$ & na \\
\hline & PVI2 & control & Rootstock trunk & $9 \mathrm{~b}$ & na \\
\hline & UCB-1 & $+\mathrm{B}$ & Potting medium & $54 \mathrm{~b}$ & na \\
\hline & UCB-1 & control & Potting medium & $14 \mathrm{a}$ & na \\
\hline & PVI2 & $+\mathrm{B}$ & Potting medium & $79 \mathrm{c}$ & na \\
\hline & PVI2 & control & Potting medium & $16 \mathrm{a}$ & na \\
\hline
\end{tabular}

z" +B" denotes pots with added B and "control" without.

${ }^{\mathrm{y}}$ Values followed by different letters in the same column for a given year and tissue type denote significant differences by Fisher's protected least significant difference test at $P \leq 0.05$.

${ }^{\mathrm{x}}$ na-not available.

in leaflets among the rootstocks and/or B treatment.

Expt. 1 compared B concentration in the leaflets of UCB-1 and PVI2 rootstocks grown in pots. In 2019, UCB-1 showed nearly double the leaflet $\mathrm{B}$ concentration of PVI2 in the $+\mathrm{B}($ added $\mathrm{B})$ treatments (Table 1).

In 2020, UCB-1 again showed higher leaflet $\mathrm{B}$ in the $+\mathrm{B}$ treatments even though $\mathrm{B}$ was higher in the potting medium of PVI2 pots. Leaflet B concentration was much lower and not different between rootstock cultivars in the control treatments in 2019 and 2020 (Table 1). Leaflet $\mathrm{Cl}$ concentration was unaffected by $\mathrm{B}$ treatment, but PVI2 leaflet $\mathrm{Cl}$ concentrations were nearly double those of UCB-1 in 2019 and nearly triple those of UCB-1 in 2020. Leaflets did not show any marginal leaf necrosis in the control or $+\mathrm{B}$ treatments, and plant growth based on visual appearance in 2019 and 2020 and trunk diameter at the end of the experiment were not different between the control and $+\mathrm{B}$ treatments for each rootstock variety. At the end of the experiment in 2020, the rootstocks were destructively sampled for B only, and no differences in B were found between the trunk wood-tissues of the two rootstocks, although $\mathrm{B}$ was higher in wood of both rootstocks in the $+\mathrm{B}$ treatments compared with the control treatments (Table 1).

Expts. 2 and 3 were performed in the field to test differences in B leaflet concentration between grafted seedling UCB-1 vs. crosses of seedling hybrids of $P$. vera and $P$. integerrima in which $P$. integerrima heritage predominated. Leaflet B in the 'Golden Hills' scion grafted onto UCB-1 rootstock was more than twice that of the hybrid $P$. vera rootstocks (PVI2 and PVI3) in all years measured in Expt. 2 (Table 2) and almost twice as high in 'Gumdrop' on UCB-1 the single year of measurement in Expt. 3 (Table 3).

In Expt. 3, the average value of soil B of $2.2 \mathrm{mg} \cdot \mathrm{L}^{-1} \pm 1.7$ (Table 3 ) may overestimate in the Expt. 2 orchard, 2017-20. ${ }^{x}$ na-not available.
2 , the high concentrations of leaflet $\mathrm{B}$ in UCB-1 rootstock trees, of nearly $2000 \mathrm{ppm}$ (Table 2), resulted in severe leaf necrosis resulting in the loss of a large percentage of the tree canopy by early September every year. Estimates of leaf canopy necrosis by early September ranged from $50 \%$ to $80 \%$ in UCB- 1 compared with $0 \%$ to $10 \%$ in the $P$. vera hybrids. When measured in 2018 , B in 'Golden Hills' shoots was almost twice as high on UCB-1 rootstock, while B in the developing nuts was more than twice as high compared with the PVI2 and PVI3 rootstocks (Table 2). Boron concentrations in rootstock trunk tissue were not different between UCB1, PVI2, and PVI3 rootstocks when measured in 2018 and 2020 but B concentration in the lower trunk of the scion was $60 \%$ higher in 'UCB-1' compared with the PVI2 and PVI3 rootstocks in 2020.

Chloride was the only other nutrient elements to show some difference in leaflet concentration among rootstocks in Expt. 2, but only in 2017. However, there was a general trend toward more elevated average leaflet $\mathrm{Cl}$ in all measurement years in the PVI2 and PVI3 rootstocks during Expt. 2.

In Expt. 2, $\mathrm{Na}$ was higher in the bark and wood of UCB-1 rootstock, but not the scion, compared with PVI2 and PVI3 in 2020 (Table 4). When the $\mathrm{B}, \mathrm{Cl}$, and $\mathrm{Na}$

Table 2. Boron (B) and chloride $(\mathrm{Cl})$ concentration in leaflet, vegetative shoots, nuts, and trunk tissue of 6- to 9-year-old trees on UCB-1, PVI2, and PVI3 rootstocks grafted to 'Golden Hills' scion

\begin{tabular}{|c|c|c|c|c|}
\hline $\mathrm{Yr}$ & Rootstock & Tissue type or soil & $\mathrm{B}\left(\mathrm{mg} \cdot \mathrm{kg}^{-1}\right)$ & $\mathrm{Cl}(\%)$ \\
\hline \multirow[t]{3}{*}{2017} & UCB-1 & Leaflet & $1337 \mathrm{a}^{\mathrm{z}}$ & $0.22 \mathrm{a}^{\mathrm{z}}$ \\
\hline & PVI2 & Leaflet & $550 \mathrm{~b}$ & $0.29 \mathrm{~b}$ \\
\hline & PVI3 & Leaflet & $597 \mathrm{~b}$ & $0.33 \mathrm{~b}$ \\
\hline \multirow[t]{12}{*}{2018} & UCB-1 & Leaflet & $1997 \mathrm{a}$ & $0.14 \mathrm{a}$ \\
\hline & PVI2 & Leaflet & $583 \mathrm{~b}$ & $0.28 \mathrm{a}$ \\
\hline & PVI3 & Leaflet & $592 \mathrm{~b}$ & $0.29 \mathrm{a}$ \\
\hline & UCB-1 & Shoot & $40 \mathrm{a}$ & $0.01 \mathrm{a}$ \\
\hline & PVI2 & Shoot & $24 \mathrm{~b}$ & $0.01 \mathrm{a}$ \\
\hline & PVI3 & Shoot & $27 \mathrm{~b}$ & $0.01 \mathrm{a}$ \\
\hline & UCB-1 & Nut & $77 \mathrm{a}$ & $0.02 \mathrm{a}$ \\
\hline & PVI2 & Nut & $30 \mathrm{~b}$ & $0.02 \mathrm{a}$ \\
\hline & PVI3 & Nut & $28 \mathrm{~b}$ & $0.02 \mathrm{a}$ \\
\hline & UCB-1 & Rootstock trunk & $56 \mathrm{a}$ & $n a^{x}$ \\
\hline & PVI2 and PVI3 & Rootstock trunk & $33 a$ & na \\
\hline & & Soil $^{\mathrm{y}}$ & $5.9 \pm 0.7$ & $35.9 \pm 9.6$ \\
\hline \multirow[t]{4}{*}{2019} & UCB-1 & Leaflet & $1871 \mathrm{a}$ & $0.33 \mathrm{a}$ \\
\hline & PVI2 & Leaflet & $781 \mathrm{~b}$ & $0.43 \mathrm{a}$ \\
\hline & PVI3 & Leaflet & $930 \mathrm{~b}$ & $0.31 \mathrm{a}$ \\
\hline & & Soill $^{\mathrm{y}}$ & $3.4 \pm 1.9$ & $9.8 \pm 6.2$ \\
\hline \multirow[t]{10}{*}{2020} & UCB-1 & Leaflet & $1865 \mathrm{a}$ & $0.29 \mathrm{a}$ \\
\hline & PVI2 & Leaflet & $692 \mathrm{~b}$ & $0.49 \mathrm{a}$ \\
\hline & PVI3 & Leaflet & $985 \mathrm{~b}$ & $0.43 \mathrm{a}$ \\
\hline & UCB-1 & Scion trunk & $28 \mathrm{a}$ & $0.01 \mathrm{a}$ \\
\hline & PVI2 & Scion trunk & $17 \mathrm{~b}$ & $0.01 \mathrm{a}$ \\
\hline & PVI3 & Scion trunk & $18 \mathrm{~b}$ & $0.01 \mathrm{a}$ \\
\hline & UCB-1 & Rootstock trunk & $42 \mathrm{a}$ & $0.02 \mathrm{a}$ \\
\hline & PVI2 & Rootstock trunk & $29 \mathrm{a}$ & $0.02 \mathrm{a}$ \\
\hline & PVI3 & Rootstock trunk & $23 \mathrm{a}$ & $0.01 \mathrm{~b}$ \\
\hline & & Soil $^{\mathrm{y}}$ & $2.6 \pm 0.2$ & $13.8 \pm 1.1$ \\
\hline
\end{tabular}

$\overline{\mathrm{z}}$ Values followed by different letters in the same column for a given year and tissue type denote significant differences by Fisher's protected least significant difference test at $P \leq 0.05$.

${ }^{y_{S}}$ Soil saturated paste extracts \pm 1 SD of $B\left(m g \cdot \mathrm{L}^{-1}\right)$ or $\mathrm{Cl}\left(\mathrm{meq} \cdot \mathrm{L}^{-1}\right)$ in the top $0.9 \mathrm{~m}$ of soil profile. 
Table 3. Boron (B) and chloride $(\mathrm{Cl})$ leaflet concentration in 5-year-old 'Gumdrop' scions grafted to UCB-1, PVI2, and PVI3 rootstocks in the Expt. 3 orchard, 2020.

\begin{tabular}{lll}
\hline Rootstock & $\mathrm{B}^{\mathrm{z}}\left(\mathrm{mg}^{\mathrm{k}} \cdot \mathrm{kg}^{-1}\right)$ & $\mathrm{Cl}^{\mathrm{z}}(\%)$ \\
\hline UCB-1 & $272 \mathrm{a}^{\mathrm{y}}$ & $0.22 \mathrm{a}$ \\
PVI2 & $145 \mathrm{~b}$ & $0.22 \mathrm{a}$ \\
PVI3 & $144 \mathrm{~b}$ & $0.24 \mathrm{a}$ \\
\hline
\end{tabular}

${ }^{\mathrm{z}}$ Soil saturated paste extracts of these elements $( \pm 1 \mathrm{SD})$ were as follows: $\mathrm{B}\left(2.2 \pm 1.7 \mathrm{mg} \cdot \mathrm{L}^{-1}\right)$ and $\mathrm{Cl}\left(23.1 \pm 6.4 \mathrm{meq} \cdot \mathrm{L}^{-1}\right)$ in the top $0.9 \mathrm{~m}$ of soil profile.

${ }^{\mathrm{y}}$ Values followed by different letters in the same column denote significant differences by Fisher's protected least significant difference test at $P \leq$ 0.05 .

concentrations of the lower-trunk scion are compared with those in the rootstock, independent of the rootstock cultivar on which the 'Golden Hills' is grafted, the scion concentration was less for each of these elements (Table 5).

Despite the increased concentration of $\mathrm{B}$ in plant tissues, especially the leaflets, and subsequent leaflet necrosis and drop in UCB1 , cumulative nut yield (data not shown) and annual nut yield was not different between UCB-1 and the rootstocks having $P$. vera heritage (Fig. 1).

In all harvest years, 'Golden Hills' scions on PVI2 and PVI3 rootstocks were harvestable 2 to $4 \mathrm{~d}$ before scions on UCB-1 rootstocks (data not shown).

Expt. 4 data were measured within a bearing commercial orchard to test differences in B leaflet concentration among grafted UCB-1, 'Platinum', and End-2 interspecific hybrid seedlings. In 2020, leaflet B in the 'Lost Hills' scion grafted onto UCB-1 rootstock was highest, with End-2 the lowest. 'Platinum' rootstock levels were intermediate (Table 6).

Relative concentrations of $\mathrm{Cl}$ were reversed, with UCB-1 having the lowest and End-2 rootstocks the highest. Again, 'Platinum' rootstock levels were intermediate. This experiment was the only one in which $\mathrm{K}$ concentration varied between leaflets with $P$. vera heritage and the commercial rootstocks without $P$. vera heritage. Potassium was highest in 'Platinum', lowest in End-2 and intermediate in UCB-1.

Expt. 5 was located in a trial within a commercial orchard where ungrafted End-2 and $P$. vera seedlings were allowed to grow into trees (8-years-old in 2020). Soil B concentrations at this site were the lowest of any of the experimental locations at $0.31 \mathrm{mg} \cdot \mathrm{L}^{-1}$. Leaflet $\mathrm{B}$ concentrations were not different in 2020 in trees having either all or a large percentage of their parentage from $P$. vera

Table 4. Sodium (Na) concentration in a core of bark, cambium, and outer wood taken $200 \mathrm{~mm}$ above and below the graft union of 9-year-old trees in the Expt. 2 orchard, 2020.

\begin{tabular}{lccc}
\hline Variety & Rootstock Na $\left(\mathrm{mg} \cdot \mathrm{kg}^{-1}\right)$ & Scion Na $\left(\mathrm{mg} \cdot \mathrm{kg}^{-1}\right)$ & Ratio of Na scion/rootstock \\
\hline UCB-1 & $130.3 \mathrm{a}^{\mathrm{z}}$ & $72.0 \mathrm{a}$ & $0.53 \mathrm{a}$ \\
PVI2 & $72.3 \mathrm{~b}$ & $54.7 \mathrm{a}$ & $0.74 \mathrm{a}$ \\
PVI3 & $57.3 \mathrm{~b}$ & $44.0 \mathrm{a}$ & $0.74 \mathrm{a}$ \\
\hline
\end{tabular}

${ }^{\mathrm{z}}$ Values followed by different letters in the same column denote significant differences by Fisher's protected least significant difference test at $P \leq 0.05$.

(Table 7). Concentrations of $\mathrm{Cl}$ and $\mathrm{Na}$ were both higher in $P$. vera compared with the End-2 hybrids.

\section{Discussion}

Reduction in plant tissue $B$ concentration with $P$. vera $\times P$. integerrima hybrids. Results from these experiments demonstrate that $\mathrm{B}$ concentrations in leaflets of both ungrafted rootstocks and their grafted scions were reduced in $P$. vera $\times P$. integerrima hybrids compared with UCB-1 seedling rootstocks (Tables 1, 2, 3, and 6). Since UCB-1 seedlings lack $P$. vera heritage, we conclude that $P$. vera is responsible for the reduced concentration of $\mathrm{B}$ in the $P$. vera hybrids. Ferguson et al. (2002) observed that $P$. atlantica had somewhat lower levels of B in leaves but still demonstrated significant leaf necrosis. Why hybrids having $P$. vera heritage should have lower concentrations of $\mathrm{B}$ in leaflets and what physiological process mediates the differential uptake of B into the plant is not clear. Sodium interception by xylem sequestration and $\mathrm{Cl}$ recirculation in phloem may augment root exclusion of these elements in the Pistacia genus (Godfrey et al., 2019). Whether either of these processes occurs with $\mathrm{B}$ to account for the difference between rootstocks in Pistacia is not known. The observation, in Expt. 1 (Table 1) that B in the lower trunk of ungrafted juvenile rootstocks was not different between PVI2 and UCB-1 suggests that differences in the sequestration of $B$ in the tissues of the tree trunk does not explain the lower B concentration in PVI2 leaflets. Thus, the exclusion by the roots may be the major mechanism that is different. Godfrey et al. (2019) suggests recirculation of $\mathrm{Cl}$, as a negative ion, in the phloem may account for increased $\mathrm{Cl}$ exclusion in Pistacia. However, in $P$. vera, B has been shown to be relatively immobile in the phloem and recirculation as occurs with $\mathrm{Cl}$ may not be possible (Brown and $\mathrm{Hu}, 1996)$. Borate transporters have been found in a number of plant species to be involved in root growth, B transport from roots to the xylem and leaves, and plant tolerance to excessive boron through exclusion from tissues (Brdar-Jokanovic, 2020; Brown et al., 2002; Sutton et al., 2007; Wakuta et al., 2016). The presence and activity of borate transporters may differ with Pistacia species and genotypes within species and may account for differences seen in B concentrations in leaflets in this study. The presence and activity of borate transporters may be amenable to selection among and within Pistacia species and interspecific hybrids.

HortScience Vol. 57(1) January 2022
Table 5. Differences in boron (B), chloride (Cl), and sodium $(\mathrm{Na})$ concentration of the lower tree trunk, independent of rootstock variety, between the scion and rootstock of 9-year-old trees in the Expt. 2 orchard, 2020.

\begin{tabular}{lccc}
\hline Trunk Part & $\mathrm{B}\left(\mathrm{mg} \cdot \mathrm{kg}^{-1}\right)$ & $\mathrm{Cl}(\%)$ & $\mathrm{Na}\left(\mathrm{mg} \cdot \mathrm{kg}^{-1}\right)$ \\
\hline Scion & $21.1 \mathrm{a}^{\mathrm{z}}$ & $0.01 \mathrm{a}$ & $56.9 \mathrm{a}$ \\
Rootstock & $32.3 \mathrm{~b}$ & $0.02 \mathrm{~b}$ & $86.7 \mathrm{~b}$ \\
\hline
\end{tabular}

${ }^{\mathrm{z}}$ Values followed by different letters in the same column denote significant differences by Fisher's protected least significant difference test at $P \leq$ 0.05 .

The mechanism of $\mathrm{B}$ exclusion may be more complex in grafted trees. In 2020, independent of rootstock cultivar, the concentration of $\mathrm{B}, \mathrm{Cl}$, and $\mathrm{Na}$ were lower $200 \mathrm{~mm}$ above the graft union compared with concentrations $200 \mathrm{~mm}$ below the graft union in Expt. 2 (Table 5). Godfrey et al. (2019) also reported decreased concentrations of $\mathrm{Cl}$ and $\mathrm{Na}$ above the graft union in the 'Kerman' scion. Although not well understood, the grafted rootstock has been shown to play an important role in regulating physiological properties of the scion (Godfrey et al., 2019; Koepke and Dhingra, 2013). In a previous study (Kallsen and Parfitt, 2008; Kallsen et al., 2020) considerable variability existed most years in leaflet B concentration among differing scion genotypes on PG1 rootstock even though soil plant-available B and totalsoil B were similar among experimental plots. This variability among scion genotypes, all on the same rootstock, strongly suggested that the scion played a role in the concentration of $\mathrm{B}$ in scion leaflets and should be considered when evaluating the results of B nutrition studies. Sherafati et al. (2011) also noted the effect of the rootstock and scion on nutrient uptake in pistachio.

In 2018 and 2020, the B concentration of the bark and outer wood of the rootstock of older grafted trees in Expt. 2 (Table 2) did not differ among PVI rootstocks and UCB-1, unlike $\mathrm{Na}$ (Table 4), further suggesting that differences in B sequestration within the rootstock is not the principal cause of differences in B concentration among rootstocks. However in this experiment, average B trended higher in UCB-1 compared with PVI2 and PVI3 (Table 2), implying that differential rootstock exclusion or sequestration could have occurred and that further experimentation is justified.

In Expt. 2 in 2018, leaflets, young shoots and nuts, and in 2020, the lower scion trunk of 'PVI2' and 'PVI3' had about $30 \%$ to $70 \%$ of the B concentration of UCB-1 (Table 2), demonstrating that the leaf, at least in the grafted tree, is not the sole tissue with differential B concentrations. The observation in Expt. 2 that B concentration in the rootstock did not differ among rootstocks, while $\mathrm{B}$ in scion trunk, leaflet, shoot, and nut tissues did, suggests the differences in passage across the graft union was an important factor in scion $\mathrm{B}$ reduction.

$P$. vera effects $B$ and $C l$ in leaflet tissue. In contrast to the $\mathrm{B}$ reduction in leaflets of hybrid 


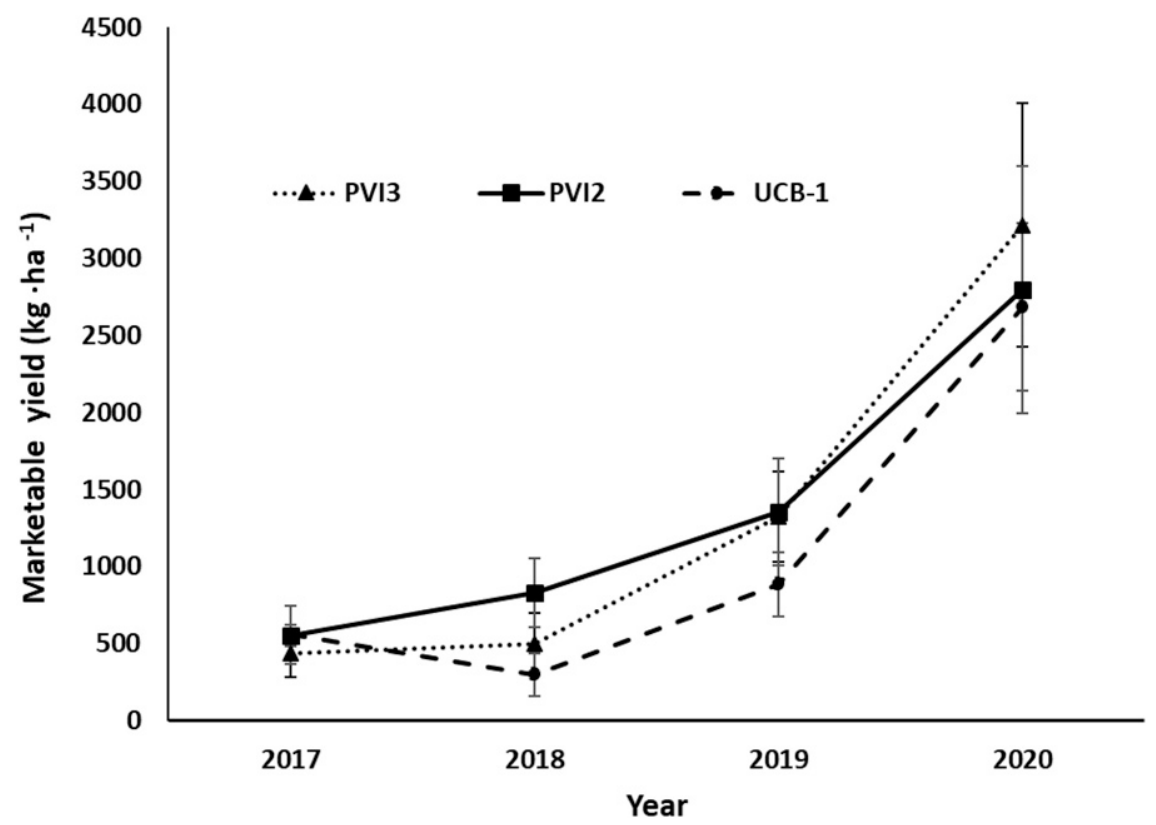

Fig. 1. Change in annual marketable yield of field-grown 'Golden Hills' pistachio trees in experimental PVI2 and PVI3 hybrid rootstocks and UCB-1 in Expt. 2. The rootstocks were planted in 2011, grafted in 2012, and the first harvest was in 2017. Error bars denote \pm 2 SE of the mean.

P. vera and $100 \%$ P. vera trees, leaflet $\mathrm{Cl}$ was often higher. Chloride concentration in ungrafted PVI2 (37.5\% P. vera) seedlings was higher compared with UCB-1 $(0 \% P$. vera $)$ in Expt. 1 (Table 1), especially in 2020. Similarly, leaflet $\mathrm{Cl}$ in ungrafted $P$. vera $(100 \% P$. vera $)$ was higher than in ungrafted End-2 (62.5\% to $75 \%$ P. vera) (Table 7). In Expt. 2, leaflet $\mathrm{Cl}$ was higher in grafted scions, especially in 2020 (Table 2), and in Expt. 4 (Table 6). In the latter two experiments, leaflet $\mathrm{Cl}$ equaled or exceeded $0.4 \%$. Critical leaflet thresholds for severe $\mathrm{Cl}$ toxicity at a leaflet concentration of greater than $0.40 \%$ were published for grafted California pistachios (Sanden et al., 2016). These "threshold" values appear to originate with Ayers and Westcot (1985), which were established for crop plants in general and not specifically for salt-tolerant pistachio. Necrosis of leaf tissue is a typical symptom of $\mathrm{Cl}$ toxicity in many crop plants (Ashworth et al., 1985).

Table 6. Boron (B), chloride $(\mathrm{Cl})$, and potassium (K) leaflet concentration in 7-year-old 'Lost Hills' scions grafted to UCB-1, 'Platinum', and End-2 rootstocks in the Expt. 4 orchard in 2020 .

\begin{tabular}{llcc}
\hline Rootstock & $\mathrm{B}^{\mathrm{z}}\left(\mathrm{mg} \cdot \mathrm{kg}^{-1}\right)$ & $\mathrm{Cl}^{\mathrm{z}}(\%)$ & $\mathrm{K}^{\mathrm{z}}(\%)$ \\
\hline $\mathrm{UCB}-1$ & $261 \mathrm{c}^{\mathrm{y}}$ & $0.20 \mathrm{a}$ & $1.7 \mathrm{~b}$ \\
Platinum & $187 \mathrm{~b}$ & $0.26 \mathrm{~b}$ & $2.0 \mathrm{c}$ \\
End-2 & $136 \mathrm{a}$ & $0.56 \mathrm{c}$ & $1.3 \mathrm{a}$ \\
\hline
\end{tabular}

${ }^{\mathrm{z}}$ Soil saturated paste extracts of these elements $( \pm 1 \mathrm{sD})$ were as follows: B $\left(0.69 \pm 0.24 \mathrm{mg} \cdot \mathrm{L}^{-1}\right)$; $\mathrm{Cl}\left(6.50 \pm 3.37 \mathrm{meq} \cdot \mathrm{L}^{-1}\right)$; or $\mathrm{K}(163.8 \pm 76.6 \mathrm{ppm} /$ $100 \mathrm{~g}$ of soil) in the top $0.9 \mathrm{~m}$ of soil profile by saturated paste extracts for $\mathrm{B}$ and $\mathrm{Cl}$ and for $\mathrm{K}$ by ammonium displacement (exchange) from the soil colloid.

${ }^{\mathrm{y}}$ Values followed by different letters in the same column denote significant differences by Fisher's protected least significant difference test at $P \leq$ 0.05 .
However, in Expt. 2, the 'Golden Hills' scion on PVI2 and PVI3 rootstocks and in Expt. 4 'Lost Hills' on End-2 rootstocks did not exhibit leaflet necrosis suggesting $\mathrm{Cl}$, at least up to $0.56 \%$ (Table 6), was not at toxic levels. Ashworth et al. (1985) reported $\mathrm{Cl}$ levels of $0.4 \%$ to $0.8 \%$ typical for 'Kerman' leaves free of scorch symptoms on $P$. atlantica rootstock, which was the major rootstock used at that time. Necrosis did not occur until leaflet concentrations were $1.9 \%$. Healthy green leaflets from 'Kerman' on $P$. integerrima rootstocks in an unrelated trial demonstrated $\mathrm{Cl}$ concentrations of $1.45 \% \pm 0.16 \%$ (SD) (L. Ferguson, personal communication). Given these observations, it may be worthwhile to reevaluate critical $\mathrm{Cl}$ leaflet concentrations for pistachio scion cultivars or, at least, adjust toxicity threshold levels for individual rootstocks.

Leaflets of the female cultivar 'Gumdrop' demonstrated differences in $\mathrm{B}$ concentration among rootstocks, but none for $\mathrm{Cl}$ in Expt. 3 (Table 3), suggesting that the scion may influence $\mathrm{Cl}$ uptake as well as the rootstock. In Expt. 4, 'Platinum' rootstock was intermediate for $\mathrm{B}$ and $\mathrm{Cl}$ concentrations demonstrating that the genetic potential for reduced uptake of $\mathrm{B}$ has not been explored in hybrids of $P$. integerrima and $P$. atlantica.

$P$. vera $\times P$. integerrima hybrids and $K$. Expt. 4 was the only experiment in which differences in $\mathrm{K}$ concentration were observed among rootstocks (Table 6). Potassium is an important macronutrient in pistachio and, based on these results, as $P$. vera heritage predominates in a rootstock, increased fertilization may be necessary to maintain adequate $\mathrm{K}$ nutrition.

$P$. vera $\times$ P. integerrima hybrids and marketable yield. Lower concentrations of $\mathrm{B}$ in the scion tissue of PVI2 and PVI3 rootstocks in Expt. 2 (Table 2), and the resultant decrease in leaf necrosis, was not associated
Table 7. Boron (B), chloride $(\mathrm{Cl})$, and sodium (Na) concentration in leaflets of ungrafted 8year-old End-2 and Pistacia vera rootstocks in the Expt. 5 orchard in 2020

\begin{tabular}{lccc}
\hline Rootstock & $\mathrm{B}^{\mathrm{z}}\left(\mathrm{mg} \cdot \mathrm{kg}^{-1}\right)$ & $\mathrm{Cl}^{\mathrm{z}}(\%)$ & $\mathrm{Na}^{\mathrm{z}}\left(\mathrm{mg} \cdot \mathrm{kg}^{-1}\right)$ \\
\hline End-2 & $99 \mathrm{a}^{\mathrm{y}}$ & $0.40 \mathrm{a}$ & $99 \mathrm{a}$ \\
$P$. vera & $100 \mathrm{a}$ & $0.55 \mathrm{~b}$ & $135 \mathrm{~b}$
\end{tabular}

${ }^{\mathrm{z}}$ Soil saturated paste extracts of these elements $( \pm 1$ SD $)$ were as follows: B $(0.31 \pm 0.15$ $\left.\mathrm{mg} \cdot \mathrm{L}^{-1}\right) ; \mathrm{Cl}(2.66 \pm 1.56) ;$ or $\mathrm{Na}(5.72 \pm 3.54$ meq $\cdot \mathrm{L}^{-1}$ ) in the top $0.9 \mathrm{~m}$ of soil profile.

${ }^{\mathrm{y}}$ Values followed by different letters in the same column denote significant differences by Fisher's protected least significant difference test at $P \leq 0.05$.

with greater annual yields for 'Golden Hills' on these rootstocks during the first four bearing years (Fig. 1). Overall tree size remained similar for the trees, regardless of rootstock. Why the repeated severe late-summer defoliation of 'Golden Hills' on UCB-1 rootstock did not result in decreased nut yield for the scion on UCB-1 is unclear. However, in annual crops, high concentrations of B in tissue and severe toxicity symptoms do not always correlate with grain yield. Barley genotypes were identified that produced greater or comparable yields to B-tolerant cultivars over a period of years under elevated soil B, even though they demonstrated high-B shoot concentrations and severe toxicity symptoms (Avci and Akar, 2005; Brdar-Jokanović, 2020). Soil B concentration in the top $0.9 \mathrm{~m}$ of soil profile within the Expt. 2 trial area decreased from 5.9 to $2.6 \mathrm{mg} \cdot \mathrm{kg}^{-1}$ from 2018 to 2020 due to reclamation efforts of the orchard owners. This reduction in soil B may be reducing B-related tree stress, however, leaflet $B$ remained high in the scions of all rootstocks in 2020 (Table 2), especially in UCB-1, with substantial defoliation. Thus, the question remains of how long comparable yields can be maintained in a perennial crop like pistachio, which has annual early leaf necrosis and extensive canopy defoliation.

Boron exclusion, by itself, is not sufficient for selection of a given rootstock for commercial purposes. Rootstocks are selected for a range of horticultural characteristics including disease, cold and drought resistance or tolerance; scion compatibility; vigor; yield; and many others. Currently, some of the experimental rootstocks discussed in this study have been or will be selected for cloning by tissue culture so that additional random and replicated experiments can be designed to compare them with existing commercial rootstocks for other important horticultural characters.

\section{Conclusions}

Inclusion of $P$. vera heritage in pistachio rootstock breeding programs is among the few approaches for reducing B in rootstock and scions when trees are grown in high-B soils. Pistacia vera heritage in our experimental rootstocks limited the concentration of leaflet B in both rootstock and scion compared with industry standard UCB-1 rootstock when grown on similar soils with 
similar irrigation water quantity and quality. By reducing $\mathrm{B}$ in plant tissues below toxic concentrations, $P$. integerrima $\times P$. vera rootstock hybrids could potentially sustain pistachio production in the SJV as soil and water $B$ levels increase. The effects of chloride tissue concentration and potential toxicity thresholds, both in rootstocks and scion, requires further investigation. In the SJV, excessive $\mathrm{B}$ and $\mathrm{Cl}$ typically exist together in saline soils. Potential rootstocks should reduce tissue concentrations of both of these elements below toxic thresholds.

Our results demonstrate that genetic variation in B uptake in Pistacia species and interspecific hybrids, and among individual seedlings within populations, allows the breeding of pistachio rootstocks more tolerant of excess B.

\section{Literature Cited}

Anderson III, H.P. and K.L. Puryear. 2002. Pistachio rootstock named 'P.N. 1-15' United States Plant Patent. USPP14706P3. 8/30/2002.

AOAC. 2016. Association of agricultural Chemists official method 972.43, Microchemical determination of carbon, hydrogen, and nitrogen, automated method, in official methods of analysis of AOAC international. 18th ed. Revision 1, 2006. Chapter 12, p. 5-6, AOAC International, Gaithersburg, MD.

Ashworth, L.J., Jr., S.A. Gaona, and E. Surber. 1985. Nutritional diseases of pistachio trees: Potassium and phosphorous deficiencies and chloride and boron toxicities. Phytopathology 75:1084-1091, https://doi.org/10.1094/PHYTO-75-1084.

Avci, M. and T. Akar. 2005. Severity and spatial distribution of boron toxicity in barley cultivated areas of central Anatolia and transitional zones. Turk. J. Agr. For. 29:377-382.

Ayers, R.D. and D.W. Westcot. 1985. Water quality for agriculture. FAO Irrigation and Drainage Paper 29 Rev. 1, FAO, Rome. <http://www. fao.org/3/t0234e/T0234E01.htm\#ch1.2.3>.

Banihashemi, Z. 1995. Identification of Phytophthora species associated with pistachio gummosis in southern Iran. Acta Hort. 419:349-352, https:// doi.org/10.17660/ActaHortic.1995.419.58.

Banuelos, G.S. 2014. Coping with naturally high levels of soil salinity and boron in the westside of central California. Perspect. Sci. 3:4-6, https://doi.org/10.1016/j.pisc.2014.11.018.

Beede, R.H., P.H. Brown, C.E. Kallsen, and S.A. Weinbaum. 2016. Diagnosing and correcting nutrient deficiencies, p. 173-188. In: L. Ferguson and D. Haviland (eds.). Pistachio production manual. UC ANR Publication 3545. Oakland CA.

Bingham, F.T., R.J. Arkley, N.T. Coleman, and G.R. Bradford. 1970. Characteristics of high boron soils in western Kern County. Hilgardia 40:193-204, https://doi.org/10.3733/hilg.v40n07p193.

Brdar-Jokanović, M. 2020. Boron toxicity and deficiency in agricultural plants. Int. J. Mol. Sci. 21:1424-1444, https://doi.org/10.3390/ijms2104 1424.

Brown, P.H. 1995. Nutrition of pistachio. Acta Hort. 419:77-78, https://doi.org/10.17660/ActaHortic. 1995.419.10.

Brown, P.H., L. Ferguson, and G. Picchioni. 1993. Boron nutrition of pistachio: Final report. Calif. Pistachio Ind. Annu. Rpt. 1993, 57-59. Calif. Pistachio Commission, Fresno.

Brown, P.H. and H. Hu. 1996. Phloem mobility of boron is species dependent: Evidence for phloem mobility in sorbitol-rich species. Ann. Bot. 77:497-505, https://doi.org/10.1006/anbo.1996. 0060.

Brown, P.H., N. Bellaloui, M.A. Wimmer, E.S. Bassil, J. Ruiz, H. Hu, H. Pfeffer, F. Dannel, and V. Römheld. 2002. Boron in plant biology. Plant Biol. 4:205-222, https://doi.org/10.1055/ s-2002-25740.

Burton, C.A., J.L. Shelton, and K. Belitz. 2012. Status and understanding of groundwater quality in the two southern San Joaquin Valley study units, 2005-2006 - Calif. GAMA Priority Basin Project. Scientific Investigations Rept. 2011-5218. USGS, https://doi.org/10.3133/sir20115218.

California Pistachio Commission. 1990. United States standards for grades of pistachio nuts, quality grades and handling guide. Calif. Pistachio Commission, Fresno, Calif.

Christensen, L.P., R.S. Ayers, and A.N. Kasimatis. 1974. Boron and salinity in vineyards of the west side, Fresno County. Calif. Agr. 28(8):10-11.

Communar, G. and R. Keren. 2006. Rate-limited transport in soils: The effect of soil texture and solution pH. Soil Sci. Soc. Amer. J. 70:882-892, https://doi.org/10.2136/sssaj2005.0259.

Ferguson, L., J.A. Ross, S.R. Grattan, C. Grieve, D. Wang, T. Donovan, and C.T. Chao. 2002. Pistachio rootstocks influence scion growth and ion relations under salinity and boron stress. J. Amer. Soc. Hort. Sci. 127:194-199, https://doi. org/10.21273/JASHS.127.2.194.

Fichtner, E.J., C.E. Kallsen, S. Dhaouadi, and C.L. Blomquist. 2017. First report of Phytophthora taxon walnut on Pistacia vera in California. Plant Dis. 101:1059.

Godfrey, J.M., L. Ferguson, B.L. Sanden, A. Tixier, O. Sperling, S.R. Grattan, and M.A. Zwienieki. 2019. Sodium interception by xylem parenchyma and chloride recirculation in phloem may augment exclusion in the salt tolerant Pistacia genus: Context for salinity studies on tree crops. Tree Physiol. 39:1484-1498, https://doi.org/10.1093/treephys/tpz054.

Goldberg, S. and R.A. Glaubig. 1986. Boron adsorption on California soils. Soil Sci. Soc. Amer. J. 50:1173-1176, https://doi.org/10.2136/ sssaj1986.03615995005000050016x.

Hanson, B., S.R. Gratton, and A. Fulton. 2006 Agricultural salinity and drainage. U.C. ANR Publications 3375. <https://anrcatalog.ucanr.edu/ Details.aspx? itemNo $=3375>$.

Hokmabadi, H., K. Arzani, and F. Hadavi. 2006. Growth and leaf chemical composition of three pistachio (Pistacia vera L.) rootstock seedlings in response to boron excess in irrigation water. Acta Hort. 726:363-366, https://doi.org/10.17660/ ActaHortic.2006.726.58.

Holtz, B.A. and B.L. Teviotdale. 2016. Salinity management in soil and water, p. 257-264. In: L. Ferguson and D. Haviland (eds.). Pistachio production manual. UC ANR Publication 3545. Oakland CA.

Jones, J.B. 2001. Laboratory guide for conducting soil tests and plant analysis, p. 227-228. 1st ed. CRC Press, Boca Raton, FL, https://doi.org/ 10.1201/9781420025293.

Kallsen, C.E. and D.E. Parfitt. 2008. Differences in leaf boron concentration among four pistachio genotypes. HortScience 43:1283 (abstr.).

Kallsen, C.E., D.E. Parfitt, and J. Maranto. 2020. UC pistachios show improved nut quality and are ready for harvest earlier than 'Kerman'. Calif. Ag. 74:86-93. <https://calag.ucanr.edu/ archive $/$ ?article $=$ ca. $2020 \mathrm{a} 0011>$.

Koepke, T. and A. Dhingra. 2013. Rootstock scion somatogenetic interactions in perennial composite plants. Plant Cell Rep. 32:1321-1337, https://doi.org/10.1007/s00299-013-1471-9.

Meyer, G.A. and P.N. Keliher. 1992. An overview of analysis by inductively coupled plasmaatomic emission spectrometry, p. 473-516. In: A. Montaser and D.W. Golightly (eds.). Inductively coupled plasmas in analytical atomic spectrometry. VCH Publishers, New York, NY, https://doi.org/10.1016/j.anifeedsci.2014.03.006.

Oster, J.D. and D. Wichelns. 2014. E.W. Hilgard and the history of irrigation in the San Joaquin Valley: Stunning productivity, slowly undone by inadequate drainage, p. 7-46. In: A.C. Chang and D.B. Silva (eds.). Salinity and drainage in San Joaquin Valley, California science, technology, and policy. Springer Dordrecht Heidelberg New York London, https:// doi.org/10.1007/978-94-007-6851-2.

Picchioni, G.A., S. Miyamoto, and J.B. Storey. 1991. Boron uptake and effects on growth and carbohydrate partitioning of pistachio seedlings. J. Amer. Soc. Hort. Sci. 116:706-711. <https: //journals.ashs.org/jashs/view/journals/jashs/116 /4/article-p706.xml>.

Quinn, N.W.T. 2014. The San Joaquin Valley: Salinity and drainage problems and the framework for a response, p. 47-98. In: A.C. Chang and D.B. Silva (eds.). Salinity and drainage in San Joaquin Valley, California science, technology, and policy. Springer Dordrecht Heidelberg New York London, https://doi.org/ 10.1007/978-94-007-6851-2.

Sah, R.N. and R.O. Miller. 1992. Spontaneous reaction for acid dissolution of biological tissues in closed vessels. Anal. Chem. 64:230-233, https://doi.org/10.1021/ac00026a026.

Sanden, B., A.E. Fulton, and L. Ferguson. 2016. Salinity management in soil and water. Chapter 15, p. 153-171. In: L. Ferguson and D. Haviland (eds.). Pistachio production manual. UC ANR Publication 3545. Oakland, CA.

Sherafati, A., H. Hokmabadi, and M. Taheri. 2011. Effects of some rootstocks on mineral nutrient uptake in two pistachio cultivars (Pistacia vera L.). Acta Hort. 912:197-201, https://doi.org/ 10.17660/ActaHortic.2011.912.28.

Su, C. and D.L. Suarez. 2004. Boron release from weathering of illites, serpentine, shales, and illitic/palygorkitic soils. Soil Sci. Soc. Amer. J. 689:96-105, https://doi.org/10.2136/ssaj2004. 9600.

Sutton, T., U. Baumann, J. Hayes, N.C. Collins, B.J. Shi, T. Schnurbusch, A. Hay, G. Mayo, M. Pallotta, M. Tester, and P. Langridge. 2007. Boron-toxicity tolerance in barley arising from efflux transporter amplification. Science 318: 1446-1449, https://doi.org/10.1126/science.1146 853.

Thomas, G.W. 1982. Exchangeable cations, p. 159-165. In: A.L. Page et al. (ed.). Methods of soil analysis: Part 2. Chemical and microbiological properties. ASA Monograph No. 9, https://doi.org/10.2134/agronmonogr 9.2.2ed.

UC ANR Laboratory. 2021. Methods of analysis. 27 Jan. 2021. < https://anlab.ucdavis.edu/ methods-of-analysis $>$.

U.S. Department of Agriculture (USDA). 2021. NRCS Soil Survey. 9 Feb. 2021. <Websoil survey.ncrs.usda.gov/ $>$.

Wakuta, S., T. Fujikawa, S. Naito, and J. Takano. 2016. Tolerance to excess-boron conditions acquired by stabilization of a BOR1 variant with weak polarity in Arabidopsis. Front. Cell and Dev. Bio. 4:4, https://doi.org/10.3389/ fcell.2016.00004. 